\title{
MAGYARORSZÁG ENERGIASTRATÉGIÁJA A KLÍMASEMLEGESSÉG TÜKRÉBEN
}

\author{
Veres Gábor Pál \\ PhD hallgató, Miskolci Egyetem, Kőolaj és Földgáz Intézet, Gázmérnöki Intézeti Tanszék \\ 3515 Miskolc, Miskolc-Egyetemváros, e-mail: veresgaborpal@gmail.com
}

\begin{abstract}
Absztrakt
Az Innovációs és Technológiai Minisztérium (ITM) 2020. év elején közzétette az elfogadott energia- és klímapolitikai stratégiai dokumentumokat, amelyek meghatározzák Magyarország rövid- és hosszútávú energiastratégiáját. A stratégia alapvetö célkitüzései megfelelnek az Európai Tanács 2019. december 12-i következtetéseiben foglaltakkal, miszerint fokozni kell a globális éghajlat-politikai fellépést. Magyarország Kormánya a megfogalmazott akciótervekkel igyekszik megvalósitani azt a célkitüzést, hogy az Európai Unió és a világ többi vezetö gazdasági hatalma, a Párizsi Megállapodásban kitüzött célokkal összhangban, legkésöbb 2050-re klímasemlegessé váljon. Ez a vállalás fogja meghatározni a magyarországi energiaszektor, és a legnagyobb energiaszükségletü iparágak elkövetkezö évtizedeit. Cikkemben bemutatom az eddigi energetikai trendek és mutatók alakulását, hogy mélyebb betekintést nyerjen az olvasó a szintén elemezni kívánt hat, úgynevezett „,zászlóshajó-projektek”-be, amelyek az ITM által beazonositásra kerültek és a legfontosabb beavatkozási területeket fedik le.
\end{abstract}

Kulcsszavak: klimastratégia, szén-dioxid kibocsátás, energiapolitika, carbon capture and storage $(C C S)$

\begin{abstract}
In the beginning of 2020, the Ministry of Innovation and Technology (ITM) published the adopted energy and climate policy strategy documents, which define Hungary's short- and long-term energy strategy. The key objectives of the strategy are in line with the European Council conclusions of 12 December 2019 on stepping up global climate action. With the action plans formulated, the Government of Hungary seeks to achieve the goal of making the European Union and the world's other leading economic powers climate-neutral by 2050, in line with the goals set in the Paris Agreement. This commitment will determine the Hungarian energy sector and the industries with the greatest energy needs for the coming decades. In my article I present the evolution of energy trends and indicators so far to give the reader a deeper insight into the six so-called "flagship projects" that also want to be analyzed, which have been indentified by ITM and cover key areas of intervention.
\end{abstract}

Keywords: climate strategy, carbon-dioxide emissions, energy policy, carbon capture and storage $(C C S)$ 


\section{Bevezetés}

A klímaváltozással foglalkozó szakemberek véleménye megoszlik azzal kapcsolatban, hogy a globális felmelegedés jelenségét teljes mértékben az emberi tevékenységeknek lehet-e tulajdonítani. Ezen soroknak nem célja ebben döntést hozni, az azonban biztos, hogy az ipari forradalom óta, mióta regisztrált hőmérséklet adatok a rendelkezésünkre állnak, a globális átlaghőmérséklet emelkedik. A 2015-ben 195 ország által elfogadott párizsi egyezmény fö célkitüzése, hogy a klímaváltozásért felelős globális felmelegedést csökkentsék a világon. Az egyezmény $2^{\circ} \mathrm{C}$ alá korlátozza a globális átlaghőmérséklet emelkedését 2050-ig, az ipari forradalom idején mért átlaghőmérséklethez képest. Továbbá elöírja, hogy az aláíró országok tegyenek erőfeszítéseket annak érdekében, hogy a felmelegedés ne haladja meg az $1,5^{\circ} \mathrm{C}$-ot. Az Éghajlatváltozási Kormányközi Testület (The Intergovernmental Panel on Climate Change, azaz IPCC) szerint, ezen a célok eléréséhez elengedhetetlen, hogy 2050-ig elérjük a karbonsemlegességet.

Fontosnak érzem megjegyezni, hogy az elérhető energia stratégiával foglalkozó szakirodalmak többségében bár az ÜHG gázok (üvegházhatást okozó gázok) mennyiségét tonnaCO $\mathrm{O}_{2} \mathrm{e}-$ ben határozzák meg (tonna ÜHG $\mathrm{CO}_{2}$ egyenértékre számolva), sokszor tévesen a kibocsátott üvegházhatású gázok mennyiségét a szén-dioxid kibocsátás mennyiségével teszik egyenlővé, pedig az ÜHG gázok egy gyüjtőnév, ami magában foglalja többek között a $\mathrm{CO}_{2}, \mathrm{CO}, \mathrm{N}_{2} \mathrm{O}, \mathrm{NO}_{\mathrm{x}}, \mathrm{SO}_{\mathrm{x}}, \mathrm{O}_{3}$, stb. gázokat is.

A karbonsemlegesség nem jelent mást, mint hogy ugyanannyi a kibocsátott szén-dioxid mennyisége, mint a különböző természetesen vagy mesterséges úton megkötött szén-dioxid mennyisége. A természetes szénelnyelők - azok a rendszerek, amelyek több szenet nyelnek el, mint amennyit kibocsátanak - tehát az erdők és az óceánok, azonban csak az éves globális szén-dioxid kibocsátásnak körülbelül legfeljebb harmadát képesek elnyelni. Mesterséges úton is lehetséges kivonni a légkörböl, vagy egyes koncentrált kibocsátási pontokból megkötni a szén-dioxidot, az ilyen megkötött szén-dioxid mennyiségek földalatti geológiai tárolókban történő elhelyezését nevezik CCS (Carbon Capture and Storage) technológiának. Ebben az eljárásban rendkívül nagy potenciál rejlik globálisan, hiszen ha a laboratóriumi szinten már müködő Underground Sun Storage (USS) és az Underground Sun Conversion (USC) projekteken belül áttörést érnének el, (mikrobaktériumok segítségével szén-dioxidból és hidrogénből metánt állítanak elő) és a mikrobaktérium törzsek tenyészthetők lennének, azokat a CCS technológia által hasznosított tárolókba lejuttatva újra kitermelhető metánt tudnánk előállítani. Ez hatalmas lépés lenne a világ karbon semlegessége felé. A laboratóriumi kutatások 2016 óta zajlanak, de az ipari szintủ alkalmazásra még biztosan várnunk kell néhány évet. Sajnos a jelenleg ismert eljárások összessége sem elegendő ahhoz, hogy egyensúlyban tartsák a kibocsátott szén-dioxid mennyiséget a megkötöttel. Ezért egyértelmüen látszik, hogy bár valószínüleg a technológiák fejlödésével javulni fog ez a mérleg, elengedhetetlenül fontos a kibocsátások csökkentése. Erre remek alternatívát kínálnak a megújuló energiaforrások, illetve más, magasabb energiahatékonysággal rendelkező technológiák nagyobb mértékủ bevonása. Nem kérdés, hogy a tagállamoktól a vállalások azonnali cselekvést és hosszútávú tervezést kívánnak.

\section{Magyarország dekarbonizációs stratégiája}

A következőkben közölt grafikonok és táblázatok a Központi Statisztikai Hivatal (KSH) és az Európai Statisztikai Hivatal (EUROSTAT) által publikált adatokból származnak, amelyek 2018-ig elérhetők.

A továbbiakban taglalt mérföldkövek és törekvések az ITM által kiadott „Nemzeti Energiastratégia 2030, kitekintéssel 2040-ig" címü stratégiában olvasható célkitüzések, a COVID-19 világjárvány 
kirobbanása előtt kerültek kiadásra, az abban leírtak mára már nagy valószínüséggel nem állják meg teljes mértékben a helyüket.

„Magyarország a világ üvegházhatású gáz (ÜHG) kibocsátásainak kb. 0,1\%-át, az EU kibocsátásainak pedig mindössze kb. 1\%-át adja”. [1] Magyarország karbon semlegességre, azaz nettó zéró ÜHG kibocsátásra törekszik 2050-re. A Párizsi Megállapodással összhangban országunk vállalta, hogy az ÜHG kibocsátásának legalább 40\%-os csökkentését valósítja meg 2030-ig az 1990. évi szinthez $\left(93,7\right.$ millió $\left.\mathrm{tCO}_{2} \mathrm{e}\right)$ képest. Ahogyan az 1. ábrán is látható az 1990-es bázisévtől 2018-ig közel 30\%-os csökkenést ért el az ország, ez az eredmény az erdészeti és egyéb földhasználati szektor (Land Use Land Use Change and Forestry, LULUCF) elnyeléseinek levonása nélkül értendö. Fontos megjegyezni, ahogyan az 1. és 2. ábrát összevetjük, látszik, hogy gazdasági növekedés nem eredményez növekvő ÜHG kibocsátást, tehát nem gátolja a környezetvédelemi törekvéseket.

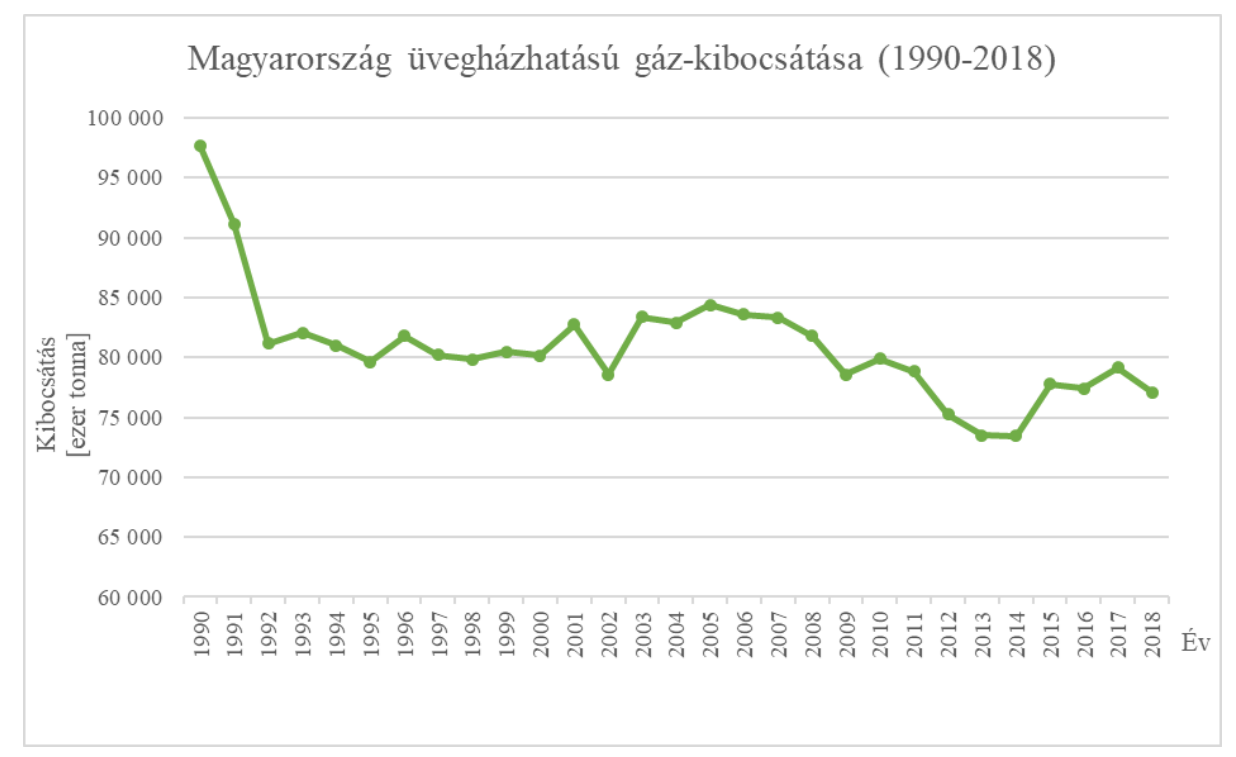

1. ábra. Magyarország ÜHG kibocsátása 1990 - 2018 [2]

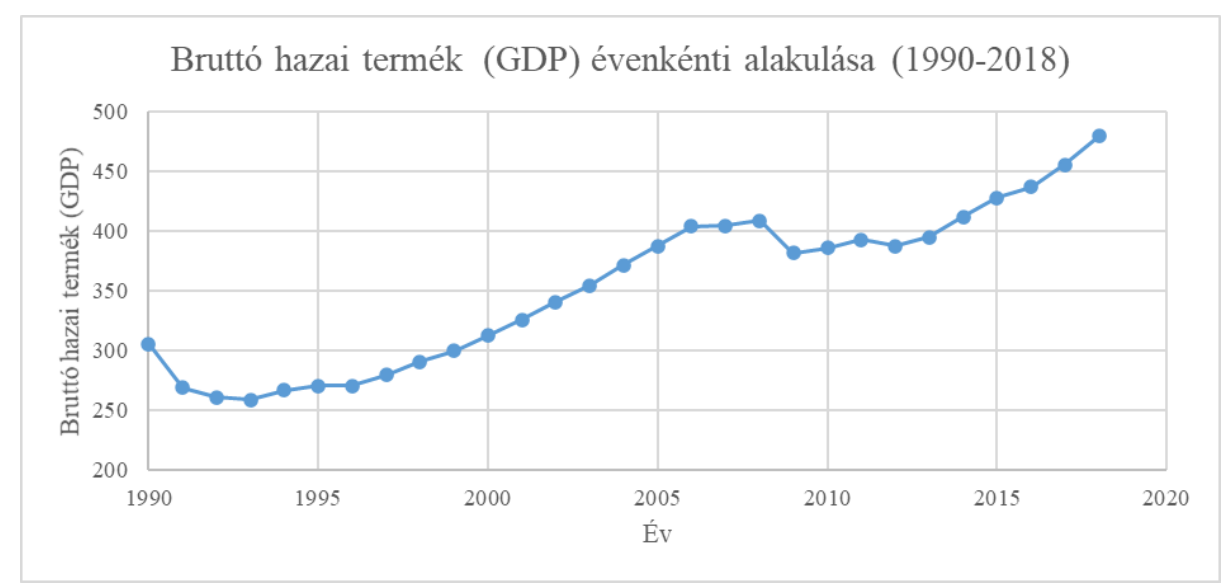

2. ábra. Magyarország GDP alakulása 1990 - 2018 [2] 
Az ITM beazonosította azokat az ágazatokat, amelyekben egyértelmü javulás érhető el annak érdekében, hogy a gazdaság karbonsemlegessé váljon 2050-re. Az átállási folyamat idő és erőforrás igényes, jelentős szerep jut majd a kifejlesztendő, ma még nem ismert technológiáknak. Ezek az ágazatok adják Magyarország ÜHG kibocsátásának legnagyobb részét. Ezen ágazatokat a 3. ábra mutatja be. „Az alábbi ágazatokban szükséges a kibocsátások abszolút nullára történő csökkentése: áram és távhő termelése, energetikai célú feldolgozóipar (olajfinomítás), kokszolás, közlekedés, energiahatékonyság, mezőgazdaság, halászat, erdészet, termékhasználat (üvegházhatású fluortartalmú gázok és oldószerek). Vannak ágazatok, amelyek esetén, a mainál jóval alacsonyabb mértékben, de várhatóan fennmaradnak az ÜHG kibocsátások, például a mezőgazdasági és az ipari kibocsátások (kisebb üzemek folyamat-emissziói, illetve az ipari energiatermelés egyes speciális folyamatai), „fugitív (bányászat vagy szállítás során elszivárgó ÜHG gázok) emissziók, régi hulladéklerakók maradék hatása". [3] Az ÜHG-t elnyelő szektorok oldalán szükséges az erdőborítottságot fokozni olyan fafajok bevonásával, amelyek ellenállóbbak a Kárpát-medence változó klímájának. A LULUCF szektor éves elnyelését stabilan legalább 4,5-5,0 millió $\mathrm{tCO}_{2} \mathrm{e}$ fölött kell tartani 2050-ig és azon túl is, ami a nettó ÜHG kibocsátás-csökkentési célhoz 5\%-kal (1990-hez képest) járulna hozzá. A szektor ÜHG nyelő kapacitása kompenzálni képes a többi ágazat nem kiváltott kibocsátási volumeneit, ezzel hozzájárulva a klímasemlegesség eléréséhez.". [3.] Az érintett iparágakra, mint azonosított beavatkozási területekre, az ITM konkrét intézkedési terveket és 2040-ig mutató víziót készített melyeknek rövid összefoglalását a következő fejezetben teszem meg.

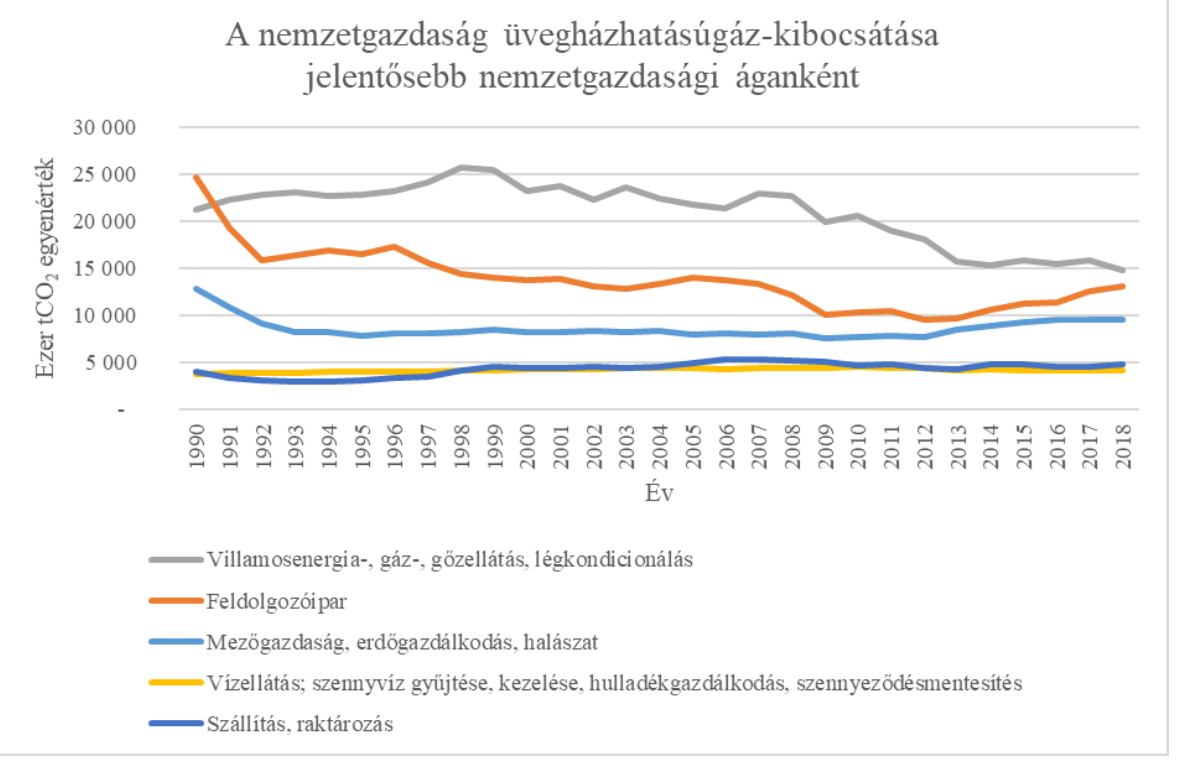

3. ábra. A nemzetgazdaság üvegházhatásúgáz-kibocsátása jelentősebb nemzetgazdasági áganként [2]

Érdekességként említeném meg, hogy a Magyar Földgáztároló Zrt. publikálta, hogy 2020-ra karbonsemlegessé vált, amelyet úgy ért el, hogy teljes villamosenergia ellátását megújuló energiaforrásokból fedezi, illetve a karbon lábnyomát olyan projektek támogatásával kompenzálja, amelyek Magyarországon, de a világ más pontján (esetükben Indiában) ellensúlyozzák a $\mathrm{CO}_{2}$ kibocsátásukat. [4] Ilyen jellegü $\mathrm{CO}_{2}$ kibocsátás kompenzációs megoldásra nem tér ki az ITM 
publikációja, azonban úgy gondolom, különösen a nagyméretủ és multinacionális vállalatok esetén, ez egy kifejezetten meggondolandó (kiegészítő) megoldás lehet.

\section{Konkrét intézkedési tervek és területek}

\subsection{Klímabarát és rugalmas áramtermelés [1]}

Egyértelmü cél a magas szintü ellátásbiztonság fenntartása, a hazai termelő kapacitások megőrzése és fejlesztése, hogy a jelenlegi villamosenergia 27,5\%-os importaránya 2040-re 20\%-ra, vagy akár az alá mérséklödjön. [5] A tervezett energiastratégiában a villamosenergia-szektornak kulcs szerepe van. A jelenlegi energiatermelési mixben a nukleáris termelőkapacitásoknak elsődleges szerepet szán továbbra is a kormány, így a dekarbonizálási stratégiában is kiemelkedően fontos szerepet tölt be Paks II megépítése és üzembe állása. A nukleáris kapacitások által biztosított megbízható rendelkezésre állás jelenti az ellátásbiztonság egyik alapkövét. A Nemzetközi Energiaügynökség (IEA) is rávilágít arra, hogy a dekarbonizációs célok megvalósítása érdekében a hatékonyság és a megújuló energiákba történő beruházások jelentős növelése mellett szükség van az atomenergia alkalmazására is. [6]

A megújuló áramtermelés bővítésének elérése egyértelmü célja a kormánynak, hiszen a beruházási költségek csökkentek, a támogatásoknak is köszönhetően a naperőmüvi beruházások lakossági is ipari méretben is felfutóban vannak. Ezt a tendenciát kívánja erősíteni a kormány a jövőben is. A szén/lignit alapú energiatermelésben a Mátrai Erőmủ blokkjainak élettartam kifuttatásával, míg a $\mathrm{CO}_{2}$ tárolási technológiában a lignit alapú energiatermelési kapacitással, mint stratégiai tartalékkal számol a kormány. A közelmúltban tapasztalt földgázpiaci változásoknak köszönhetően a földgáztüzelésü áramtermelö kapacitásokra továbbra is nagy szükség lesz, jelenleg az ország gázimport aránya $87 \%$ felett van. [7] Cél, hogy az erőmúvi mix átalakulása és a lakossági távfútési rendszer reformjának végrehajtásával ez az arány 2040-re 70\% alá csökkenjen. Annak érdekében, hogy hazánk a legkevésbé legyen kiszolgáltatott helyzetben, szükség van jelentős gázpiaci infrastruktúra fejlesztésre, melynek eredményeként négy független gáz importforrásból juthasson földgázhoz (orosz, LNG, román, nyugateurópai piacok). Ilyen már jóváhagyott fejlesztési projektek: „Északkelet-Magyarország ellátásbiztonságának növelését célzó fejlesztési projekt” vagy a „A szerb-magyar beszállítási kapacitás létrehozása $6 \mathrm{Mrdm}^{3} / \mathrm{év}$ max. kapacitással" c. projektek. [8] Alternatívaként tekint továbbá a kormány a biomassza és hidrogén alapú villamosenergia előállítás felfutására. Utóbbi előállítása akkor lehet teljesen karbon semleges, ha a bontásához szükséges energia is megújuló energiaforrásból származik, amelyre szintén zajlanak már pilot projektek, illetve kisebb innovációs kezdeményezések. Hazánkban már mindkét irányra van példa, biomassza erőmü esetén a „Bioerőmü-projekt, Szombathely” c. projektet említeném meg [9], illetve a hidrogén elóállítására a „Fronius International GmbH” „Fronius Solhub" nevü rendszerét mellyel elnyerték 2020-ban a „Smarter E Award” díjat. [10]

\subsection{Energiahatékonyság javítása [1]}

A hazai lakossági és ipari végső energiafelhasználás az elmúlt években folyamatosan emelkedett, melynek mérséklésére és hosszútávú csökkenésére számítanak a szakemberek. A köz- és lakóépületek a hazai legnagyobb $\mathrm{CO}_{2}$ kibocsátók és egyben a legnagyobb energiafogyasztók, a kibocsátás és energiafogyasztás mértéke nagy mértékben csökkeni fog, hiszen 2030-ra kb. 2 milliárd $\mathrm{m}^{3}$ földgáz felhasználás csökkenést várnak a szakemberek a „Zöld Távhő Program” megvalósulásával, melynek célja a távhő rendszer megújítása és a megújulók jelentős bevonása. 2021. január 1-jétől közel nulla energiaigényü épületek építése engedélyezhető, ami tovább csökkenti a lakossági és ipari épületek $\mathrm{CO}_{2}$ kibocsátását. 


\subsection{Közlekedés zöldítése [1]}

A Magyar Energetikai és Közmü-szabályozási Hivatal (MEKH) adatai szerint 2018-ban Magyarországon a végsőenergia-felhasználás $18 \%$-át a közlekedési szektor adta, valamint az ÜHG emisszió 20\%-áért a közlekedési szektor a felelős. [11] A közlekedési ágazat folyamatos növekedésének ellensúlyozására személyautók és a rövid távú személy- és áruszállítás terén jelenthetnek alternatívát az elektromos jármüvek térhódítása. Ennek elengedhetetlen feltétele az állami szabályozások és infrastrukturális feltételek biztosítása.

Az ITM becslései szerint mintegy 50 ezer milliárd forintra lenne szükség ahhoz, hogy hazánk karbonsemleges villamosenergia-termeléssel rendelkezzen, a földgázfelhasználást teljes egészében kiváltsa, és a közlekedést teljes körüen elektromos alapra helyezze, ez éves szinten a GDP kb. 2,0-2,5 százalékát jelenti.

\subsection{Energiatudatos és modern magyar otthonok [1]}

A Magyar Villamosenergia-ipari Átviteli Rendszerirányító Zártkörüen Müködő Részvénytársaság (MAVIR Zrt.), illetve az FGSZ Földgázszállító Zártkörúen Müködő Részvénytársaság (FGSZ Zrt.) által készített, és a MEKH által közzétett áram- és gázszektor adatait összegző kiadványok szerint jelenleg a háztartások túlnyomó része (közel 99,6\%-a) az egyetemes szolgáltatás keretében, hatósági árakon vételez energiát. A korábban már említett „Zöld Távhő Program” célkitüzéseinek teljesülése esetén jelentősen csökkenne az energiaszükséglete a háztartásoknak. A Kormány célja, hogy a magyar családok energiafüggetlensége tovább növekedjen. Ennek érdekében a beruházási kedvet ösztönző szabályozási háttér megteremtése után, a háztartási energiafogyasztás megújuló energiaforrásokból (napelemes rendszerek és hőszivattyúk telepítésével) származó aránya elérje 2030-ra az 50\%-ot. Ezen rendszerek alkalmasak lesznek arra, hogy a termelt többlet energiát visszatáplálva a hálózatba javítsák az ellátásbiztonságot Magyarországon. Ennek elősegítésére közel minden háztartásban okos villamosenergia-fogyasztásmérőt kíván kihelyezni a Kormány. Potenciális fejlesztési területet lát a kormányzat a mezőgazdasági hulladék alapú biogáz üzemek létesítésében is.

\subsection{Energia innovációs projektek [1]}

Korábban már említésre került, hogy a karbonsemlegesség eléréséhez számos, jelenleg még nem ismert technológiai újítás szükséges, melyek kutatására és létrejöttének ösztönzésére nagy szükség lesz a következő évtizedben. Szükség van olyan források megtalálására, amelyek az előzőekben leírt törekvések teljesülését segítik. Jelenlegi tudásunk szerint eredménnyel kecsegtetnek az alábbi területek, melyekben szükséges pilot projektek indítása: energia tárolás technológiájának fejlesztése, hidrogén alapú technológiák fejlesztése, felesleges villamos energia hővé alakításának és tárolásának kutatása, elektromos jármüvek elterjedéséhez szükséges infrastrukturális fejlesztések, kimerült fütőelemek és akkumulátorok újrahasznosíthatóságának fejlesztése.

\section{4. Összefoglalás}

Fenti áttekintésből jól látszik, hogy számos olyan területe van az energia szektornak, a közlekedésnek, a különböző ipari technológiáknak, ahol jól azonosított irányba szükséges lépni a karbonsemlegesség elérése érdekében. Több olyan kezdeményezés, kutatás és projekt van már folyamatban, amelyek mind ugyanezt a célt szolgálják. Azt gondolom, az elöttünk álló évtized a környezetvédelmi innovációk évtizede lesz. Az elhatározás lakossági és kormányzati szinten már megvan, az újítások ösztönzéséhez 
szükséges források az EU-n belül léteznek, így bízom benne, hogy minden rendelkezésre áll az ÜHG kibocsátás csökkentéséhez és globális felmelegedés megállításához. Elvitathatatlan, hogy minden ember személyes hozzáállásán, energiatudatos viselkedésén is nagyban múlik, hogy a kitüzött célokat sikerül-e elérni 2050-ig. Azonban, véleményem szerint kiemelten fontos a hidrogénre alapozott, különösen a CCS, USS és az USC technológiák és a megújuló energiahordozókra alapozott technológiák széleskörü elterjedése, valamint az alternatív üzemanyagok térhódítása, a világszintü kompenzációs projektek mellett. Ezek nélkül nem lehet garantált Magyarország és az EU energiastratégiájának a sikere.

\section{Köszönetnyilvánítás}

A cikkben ismertetett kutató munka az NKFIH Alapból az Innovációs és Technológiai Minisztérium, mint Irányító szerv és az NKFIH, mint Kezelő szerv által kiírt "Kooperatív Doktori Program Doktori Hallgatói Ösztöndíj” támogatásával valósul meg.

\section{Irodalom}

[1] ITM: Nemzeti Energiastratégia 2030, kitekintéssel 2040-ig: www.mmk.hu/dokumentumok/20200117_nemzetienergiastrategia2030 (letöltve: 2020.09.14)

[2] www.ksh.hu

[3] Nemzeti Tiszta Fejlődés Stratégia - tervezet: https://ec.europa.eu/clima/sites/lts/lts_hu_hu.pdf (letöltve: 2020.09.14)

[4] http://mfgt.hu/hu-HU/Karbonsemlegesseg/MFGTKarbonsemleges?fbclid=IwAR1GjE9D0zw7RyT8BnGN6vtrmPadXjQ4zvvaNySzBHFj-e8cg1_yPE2-WE (letöltve: 2020.11.09)

[5] http://www.mekh.hu/villamosenergia-piac-2019-emelkedo-fogyasztas-bovulo-termelescsokkeno-import (letöltve: 2020.11.03)

[6] IEA (2019): Nuclear Power in a Clean Energy System. 2019. May (https://webstore.iea.org/download/direct/2779?fileName=Nuclear_Power_in_a_Clean_Energy _System.pdf) (letöltve: 2020.11.03)

[7] http://www.mekh.hu/download/c/b2/d0000/3_2_eves_foldgazmerleg_2014_2019e.xlsx (letöltve: 2020.11.03)

[8] https://fgsz.hu/file/documents/1/1744/2020_07_09_tiz_eves_fejlesztesi_terv.pdf (letöltve: 2020.11.03)

[9] https://m.szombathely.hu/kozgyules/e-bizottsag/download.22394/ (letöltve: 2020.11.03)

[10] https://www.hfc-hungary.org/H2_Hirlevel_2020_2_augusztus.pdf (letöltve: 2020.11.03)

[11] http://www.mekh.hu/download/a/c2/d0000/7_2_orszagos_eves_energiamerleg_2014_2019e.xls x (letöltve: 2020.11.09) 